This article is licensed under the Creative Commons Attribution-NonCommercial 4.0 International License (CC BY-NC) (http://www.karger.com/Services/OpenAccessLicense). Usage and distribution for commercial purposes requires written permission.

\title{
A Successfully Treated Case of Intrahepatic Cholangiocarcinoma with Exacerbation of Dermatomyositis
}

\author{
Jungo Yasuda Shinji Onda Hironori Shiozaki Takeshi Gocho \\ Hiroaki Shiba Katsuhiko Yanaga \\ Department of Surgery, The Jikei University School of Medicine, Tokyo, Japan
}

\section{Keywords}

Dermatomyositis · Intrahepatic cholangiocarcinoma $\cdot$ Paraneoplastic syndrome

\begin{abstract}
Dermatomyositis (DM) is often found in conjunction with malignant tumors such as lung, cervical, and breast cancer. However, the association with intrahepatic cholangiocarcinoma (ICC) is extremely rare. Moreover, to our knowledge, there have been no previous reports of DM discovered because of exacerbation of DM. Our case was a 44-year-old female with dry cough, myalgia, and arthralgia. We performed hepatic resection for intrahepatic ICC. She was diagnosed with DM, and combination treatment with prednisolone and tacrolimus was started. During outpatient visits, her symptoms worsened, and she was hospitalized due to deterioration of her primary disease. On detailed examination, a malignant lesion in the liver was discovered. After operation, the symptoms of DM remain stable by taking prednisolone and tacrolimus. The patient was suspected to have paraneoplastic syndrome, which was discovered due to the exacerbation of the DM that was caused by the intrahepatic ICC.

(C) 2018 The Author(s)

Published by S. Karger AG, Basel
\end{abstract}




\section{Case Reports in Gastroenterology}

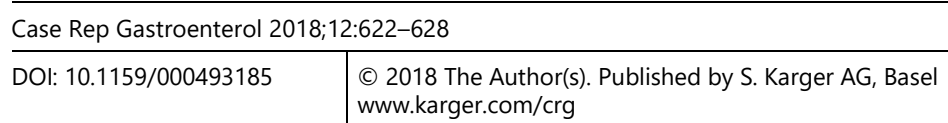
www.karger.com/crg

Yasuda et al.: A Successfully Treated Case of Intrahepatic Cholangiocarcinoma with Exacerbation of Dermatomyositis

\section{Introduction}

Dermatomyositis (DM) is an idiopathic inflammatory myositis characterized by muscle pain, muscle weakness, and skin rash [1]. DM is often concomitant with malignant tumors such as gastric cancer, lung cancer, malignant lymphoma, ovarian carcinoma, breast cancer, and colorectal cancer. Concomitant occurrence with intrahepatic cholangiocarcinoma (ICC) is extremely rare [2]. We herein report a successful treated case of ICC which was detected during exacerbation of DM.

\section{Case Presentation}

A 44-year-old female had been suffering from dry cough, myalgia, and arthralgia since 2013 and was diagnosed as DM (Table 1). Her symptoms were abated by combination treatment using prednisolone and tacrolimus. However, the cough, pyrexia, and arthralgia recurred due to the exacerbation of DM. The patient was admitted to our hospital for further checkup and treatment. Laboratory data showed that her white blood cell count and C-reactive protein levels were elevated. Her serum carcinoembryonic antigen and carbohydrate antigen 19-9 were not elevated (Table 2). Enhanced computed tomography showed a 20-mm low-density tumor with a gradual enhancement in segment 4 of the liver (Fig. 1a). Ultrasonography showed a $20-\mathrm{mm}$ tumor in segment 4 of the liver (Fig. 1b). In magnetic resonance imaging (MRI), the tumor had a weak signal intensity on T1-weighted images and a strong signal intensity on T2-weighted and diffusion-weighted images. In the dynamic study of MRI, enhancement of the edge of the tumor was gradually increased from the early to the late phase (Fig. 1c). Following the diagnosis of ICC in segment 4 of the liver, hepatic medial segmentectomy and cholecystectomy were performed. In the resected specimen, macroscopic findings consisted of a solid hepatic tumor with the diameter of $35 \times 25 \times 21 \mathrm{~mm}$ (Fig. 2). The pathological diagnosis was moderately differentiated adenocarcinoma with vascular invasions and without lymph node metastasis (pStage III). The tumor consists of cells with coarse chromatin (Fig. 3). Many of the tumors have tube formation and immunohistological findings of intrahepatic ICC and moderately differentiated adenocarcinoma with CK7 (+), CK $19(+)$, and CK $20(-)$ (Fig. 4). The patient made a satisfactory recovery with no postoperative complications and was transferred to the Department of the Internal Medicine to treat DM with tacrolimus $5 \mathrm{mg} /$ day and prednisone $20 \mathrm{mg} /$ day. The patient was discharged on postoperative day 23. Since this case was a high-risk case of stage III with vascular invasion, adjuvant chemotherapy using S-1 for 6 months was performed. The patient has remained well without recurrence of ICC or relapse of DM after hepatic resection.

\section{Discussion}

The incidence of concomitant malignant tumors in patients with DM is quite high, ranging from 15 to $32 \%$ [2, 3], and significantly higher than those in people without DM. The relative risk of cancer was 2.4 (95\% confidence interval, 1.6-3.6) in the male patients and 3.4 (95\% confidence interval, 2.4-4.7) in the female patients [3]. Among Japanese patients, the frequent 
concomitant malignant tumors with DM consist of gastric, lung, uterine, breast, and liver cancers $[4,5]$. Concomitance of ICC with DM is extremely rare.

Genetic changes caused by a viral infection or changes in the immune system such as an antigen-antibody reaction of DM may be one of the possible mechanisms of the association between DM and the development of malignant tumors [6, 7]. However, the detailed mechanisms are still unclear. There have been reported cases of malignant tumors, which were detected with the exacerbation of DM and with the improvement of the symptoms of DM after treatment of the malignant tumor [3]. One-third of the DM patients with malignant tumors are cured by treatment, including resection of the tumor [8]. We herein reported a successfully treated case of ICC by hepatic resection and adjuvant chemotherapy, which was detected with the exacerbation of DM. In the present case, the symptoms of DM improved after treatment of ICC. This case was suspected to have paraneoplastic syndrome, which was discovered due to the exacerbation of DM that was caused by the intrahepatic ICC. When these symptoms worsened, a systemic scan for malignant tumors was believed to be necessary.

\section{Statement of Ethics}

All procedures followed were in accordance with the ethical standards of the responsible committee on human experimentation (institutional and national) and with the Helsinki Declaration of 1975, as revised in 2008 (5). The patient consented to the reporting of this case in scientific publication.

\section{Disclosure Statement}

The authors declare that they have no competing interests.

\section{Funding}

This research did not receive any specific grant from funding agencies in the public, commercial, or not-for-profit sectors.

\section{Author Contributions}

S.O. and T.G. performed the operation. H. Shiozaki., H. Shiba., and K.Y. helped draft the manuscript. All authors read and approved the final manuscript. 


\section{Case Reports in Gastroenterology}

\begin{tabular}{l|l}
\hline Case Rep Gastroenterol 2018;12:622-628 \\
\hline DOI: 10.1159/000493185 & $\begin{array}{l}\text { @ 2018 The Author(s). Published by S. Karger AG, Basel } \\
\text { www.karger.com/crg }\end{array}$ \\
\hline
\end{tabular}

Yasuda et al.: A Successfully Treated Case of Intrahepatic Cholangiocarcinoma with Exacerbation of Dermatomyositis

\section{References}

1 Dalakas MC, Hohlfeld R. Polymyositis and dermatomyositis. Lancet. 2003 Sep;362(9388):971-82.

2 Hill CL, Zhang Y, Sigurgeirsson B, Pukkala E, Mellemkjaer L, Airio A, et al. Frequency of specific cancer types in dermatomyositis and polymyositis: a population-based study. Lancet. 2001 Jan;357(9250):96-100.

3 Sigurgeirsson B, Lindelöf B, Edhag O, Allander E. Risk of cancer in patients with dermatomyositis or polymyositis. A population-based study. N Engl J Med. 1992 Feb;326(6):363-7.

4 Barnes BE, Mawr B. Dermatomyositis and malignancy. A review of the literature. Ann Intern Med. 1976 Jan;84(1):68-76.

5 Requena C, Alfaro A, Traves V, Nagore E, Llombart B, Serra C, et al. Paraneoplastic dermatomyositis: a study of 12 cases. Actas Dermosifiliogr. 2014 Sep;105(7):675-82.

6 Targoff IN, Reichlin M. The association between Mi-2 antibodies and dermatomyositis. Arthritis Rheum. 1985 Jul;28(7):796-803.

7 Mierau R, Dick T, Bartz-Bazzanella P, Keller E, Albert ED, Genth E. Strong association of dermatomyositisspecific Mi-2 autoantibodies with a tryptophan at position 9 of the HLA-DR beta chain. Arthritis Rheum. 1996 May;39(5):868-76.

8 András C, Ponyi A, Constantin T, Csiki Z, Szekanecz E, Szodoray P, et al. Dermatomyositis and polymyositis associated with malignancy: a 21-year retrospective study. J Rheumatol. 2008 Mar;35(3):438-44.
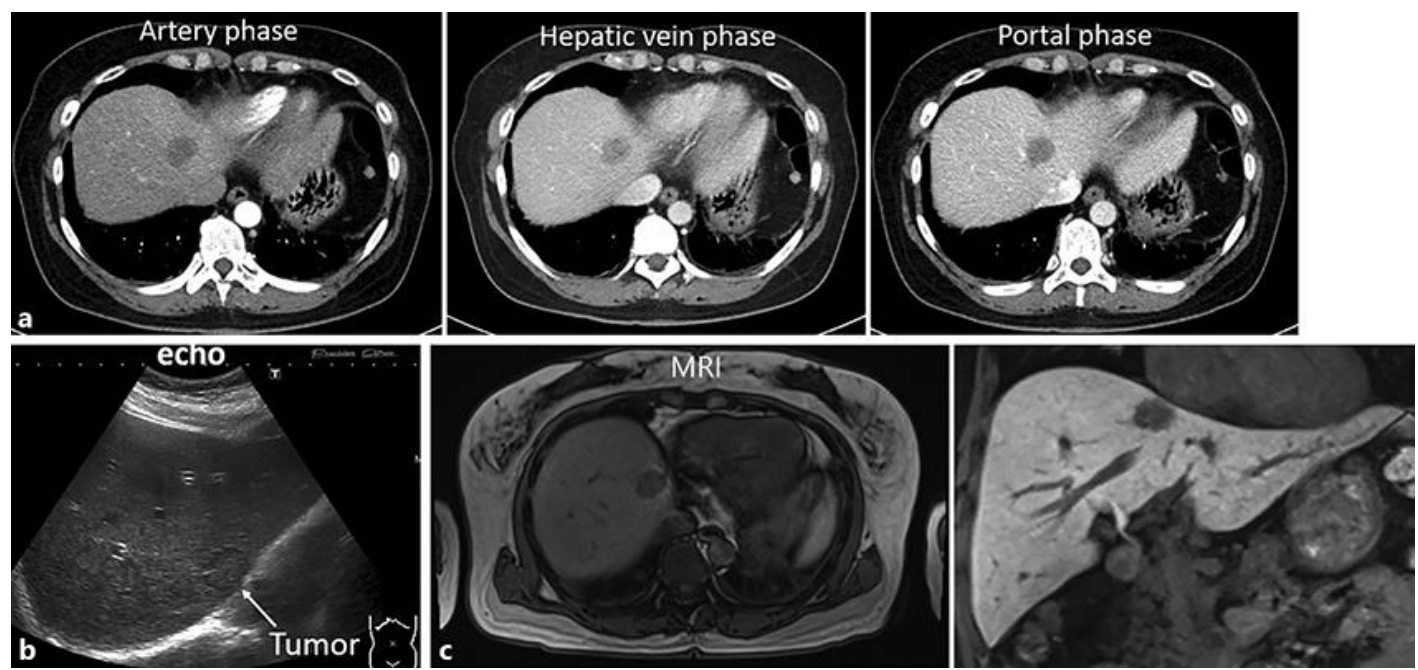

Fig. 1. Image findings. a Computed tomography showing a 20-mm low-density tumor with gradual enhancement in segment 4 of the liver. b Ultrasonography showing a 20-mm tumor in segment 4 of the liver. c In the dynamic study of MRI, enhancement of the edge of the tumor gradually increased from the early to the late phase. 


\section{Case Reports in Gastroenterology}

\begin{tabular}{l|l} 
Case Rep Gastroenterol 2018;12:622-628 \\
\hline DOI: 10.1159/000493185 & $\begin{array}{l}\text { (c) 2018 The Author(s). Published by S. Karger AG, Basel } \\
\text { www.karger.com/crg }\end{array}$ \\
\hline
\end{tabular}

Yasuda et al.: A Successfully Treated Case of Intrahepatic Cholangiocarcinoma with Exacerbation of Dermatomyositis
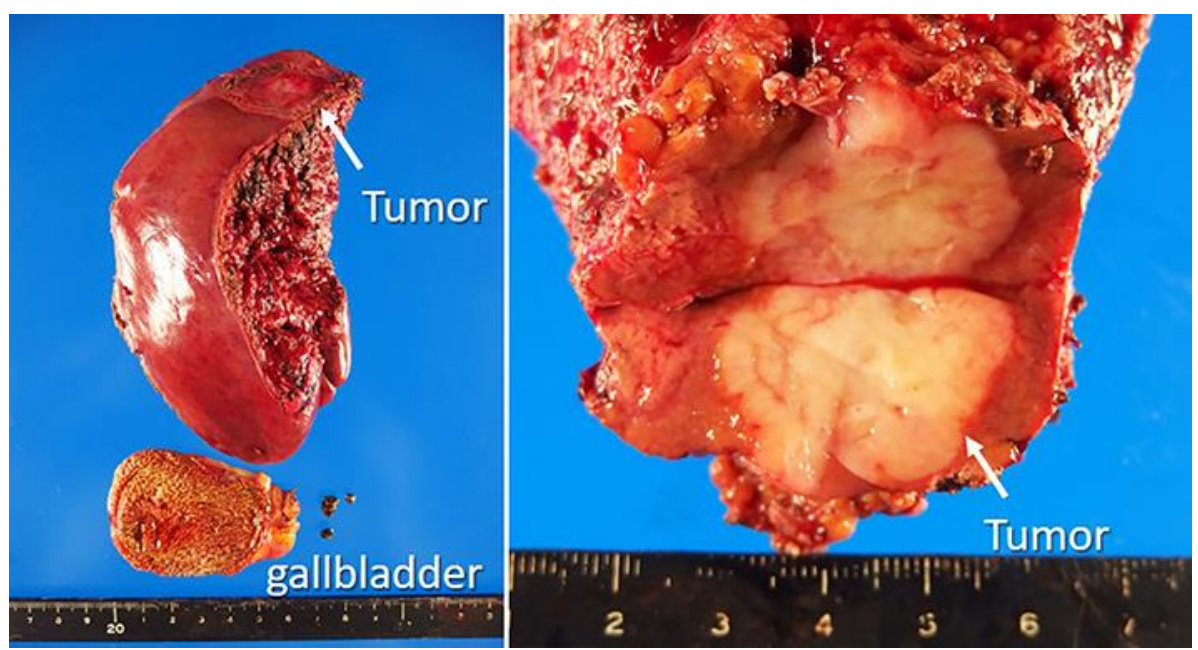

Fig. 2. Macroscopic findings. Macroscopic findings of a solid hepatic tumor with the diameter of $35 \times 25 \times$ $21 \mathrm{~mm}$.


Fig. 3. Microscopic findings (HE staining). The tumor consists of cells with coarse chromatin. 


\section{Case Reports in Gastroenterology}

\begin{tabular}{l|l}
\hline Case Rep Gastroenterol 2018;12:622-628 \\
\hline DOI: 10.1159/000493185 & $\begin{array}{l}\text { @ } 2018 \text { The Author(s). Published by S. Karger AG, Basel } \\
\text { www.karger.com/crg }\end{array}$ \\
\hline
\end{tabular}

\section{Immunostaining}
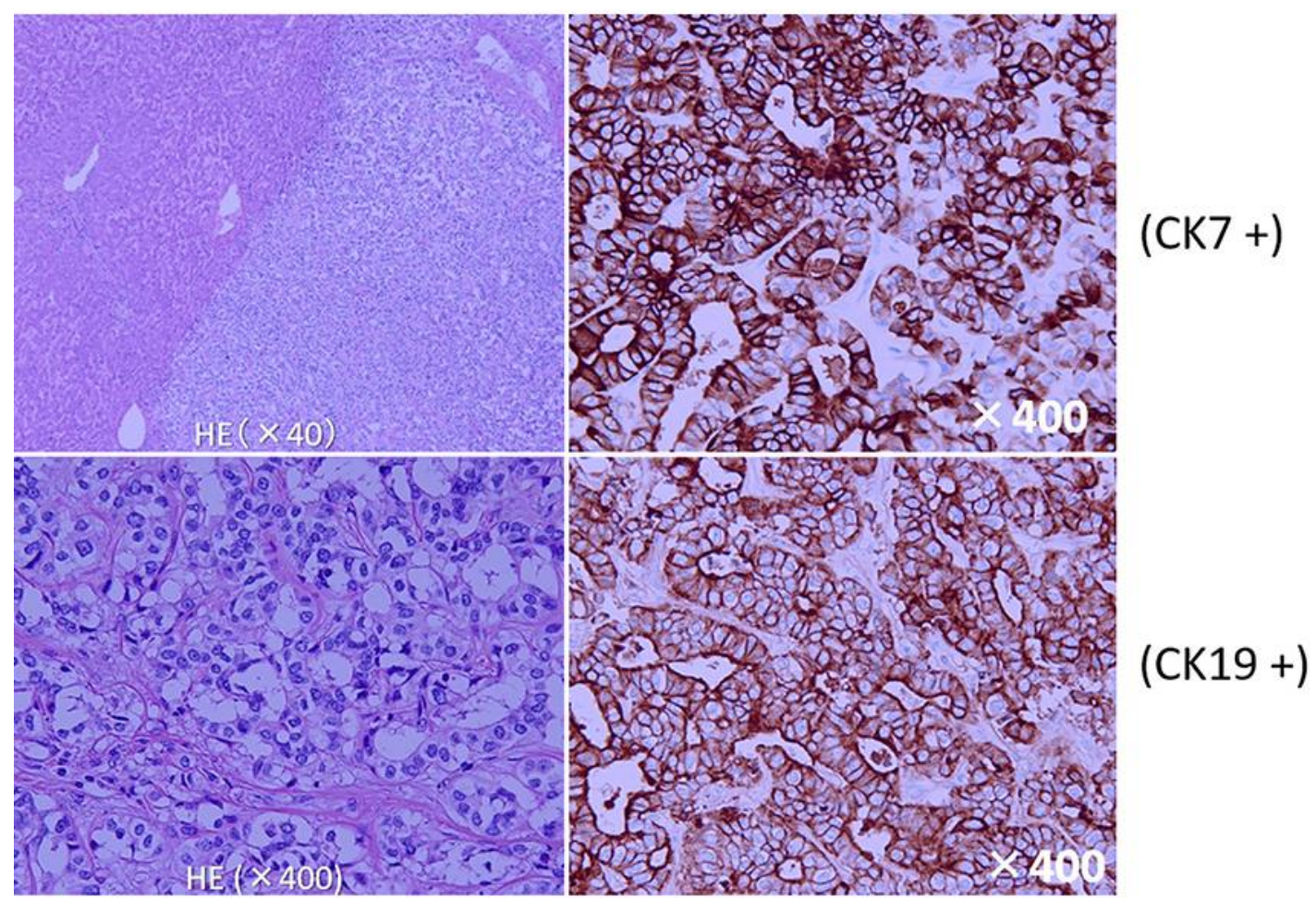

Fig. 4. Microscopic findings. Immunohistological findings of intrahepatic ICC and moderately differentiated adenocarcinoma with CK7 (+), CK 19 (+), and CK 20 (-). 
Yasuda et al.: A Successfully Treated Case of Intrahepatic Cholangiocarcinoma with Exacerbation of Dermatomyositis

Table 1. Laboratory data before treatment for DM

\begin{tabular}{llll}
\hline $\mathrm{RF}$ & $3.8 \mathrm{IU} / \mathrm{mL}$ & ANA(IF) & negative \\
$\mathrm{IgG}$ & $1,675 \mathrm{mg} / \mathrm{dL}$ & Anti-dsDNAAb & $<10 \mathrm{U} / \mathrm{mL}$ \\
$\mathrm{IgA}$ & $439 \mathrm{mg} / \mathrm{dL}$ & Anti-SmAb & $<7.0 \mathrm{U} / \mathrm{mL}$ \\
$\mathrm{IgM}$ & $158 \mathrm{mg} / \mathrm{dL}$ & Anti-SS-Aab & $<7.0 \mathrm{U} / \mathrm{mL}$ \\
$\mathrm{C} 3$ & $74 \mathrm{mg} / \mathrm{dL}$ & Anti-RNPAb & $<7.0 \mathrm{U} / \mathrm{mL}$ \\
$\mathrm{C} 4$ & $13 \mathrm{mg} / \mathrm{dL}$ & Anti-Jo-1Ab & $>500 \mathrm{U} / \mathrm{mL}$ \\
$\mathrm{CH} 50$ & $35.9 \mathrm{mg} / \mathrm{dL}$ & Anti-Scl70Ab & $<7.0 \mathrm{U} / \mathrm{mL}$ \\
$\mathrm{MMP}-3$ & $98.3 \mathrm{ng} / \mathrm{mL}$ & C-ANCA & $<1.0 \mathrm{U} / \mathrm{mL}$ \\
Anti-CCP & $<0.6 \mathrm{U} / \mathrm{mL}$ & P-ANCA & $<1.0 \mathrm{U} / \mathrm{mL}$ \\
& & Anti-TIFIAb & negative \\
\hline
\end{tabular}

Elevations other than anti-Jo-1Ab were not observed.

Table 2. Laboratory data before the operation

\begin{tabular}{|c|c|c|c|c|c|}
\hline WBC & $19,900 / \mu \mathrm{l}$ & AST & $28 \mathrm{IU} / \mathrm{L}$ & $\mathrm{TC}$ & $263 \mathrm{mg} / \mathrm{dL}$ \\
\hline $\mathrm{RBC}$ & $3.88 \times 10^{6} / \mu \mathrm{L}$ & ALT & $22 \mathrm{IU} / \mathrm{L}$ & $\mathrm{TG}$ & $113 \mathrm{mg} / \mathrm{dL}$ \\
\hline $\mathrm{Hb}$ & $12.0 \mathrm{~g} / \mathrm{dL}$ & $\mathrm{LDH}$ & $362 \mathrm{IU} / \mathrm{L}$ & $\mathrm{HbA} 1 \mathrm{C}$ & $6.1 \%$ \\
\hline $\mathrm{Ht}$ & $37.8 \%$ & ChE & $195 \mathrm{IU} / \mathrm{L}$ & & \\
\hline \multirow[t]{5}{*}{ Plt } & $377 \times 10^{3} / \mu \mathrm{L}$ & T-Bil & $0.7 \mathrm{mg} / \mathrm{dL}$ & & \\
\hline & & D-Bil & $0.1 \mathrm{mg} / \mathrm{dL}$ & & \\
\hline & & ALP & $238 \mathrm{IU} / 1$ & HBs Ag & negative \\
\hline & & $\gamma$-GTP & $32 \mathrm{IU} / \mathrm{l}$ & HCVAb & positive \\
\hline & & $\mathrm{TP}$ & $6.7 \mathrm{~g} / \mathrm{dL}$ & HCV-RNA & negative \\
\hline PT & $90 \%$ & Alb & $2.8 \mathrm{~g} / \mathrm{dL}$ & & \\
\hline PT-INR & 1.0 & UN & $8 \mathrm{mg} / \mathrm{dL}$ & & \\
\hline APTT & $31.9 \mathrm{~s}$ & $\mathrm{Cr}$ & $0.55 \mathrm{mg} / \mathrm{dL}$ & CEA & $1.2 \mathrm{ng} / \mathrm{mL}$ \\
\hline \multirow[t]{5}{*}{ Fbg } & $576 \mathrm{mg} / \mathrm{dL}$ & UA & $3.8 \mathrm{mg} / \mathrm{dL}$ & CA19-9 & $8 \mathrm{ng} / \mathrm{mL}$ \\
\hline & & $\mathrm{Na}$ & $139 \mathrm{mEq} / \mathrm{L}$ & AFP & $2 \mathrm{ng} / \mathrm{mL}$ \\
\hline & & $\mathrm{K}$ & $3.8 \mathrm{mEq} / \mathrm{L}$ & PIVKA-II & $17 \mathrm{mAu} / \mathrm{mL}$ \\
\hline & & $\mathrm{Cl}$ & $102 \mathrm{mEq} / \mathrm{L}$ & ICG(R15) & $8 \%$ \\
\hline & & CRP & $7.7 \mathrm{mg} / \mathrm{dL}$ & LHL15 & 0.964 \\
\hline
\end{tabular}

